\title{
Model of Problem Statement (MPS): A solution on Heuristic Problem in Teaching of History
}

\author{
Mohamad Zaenal Arifin Anis ${ }^{1}$, Yetti Supriyati ${ }^{2}$, Gaguk Margono ${ }^{3}$ \\ \{mzarifinanis@ulm.ac.id ${ }^{1}$,yetti.supriyati@unj.ac.id², gaguk.margono@unj.ac.id ${ }^{3}$ \} \\ ${ }^{1}$ Universitas Lambung Mangkurat, Banjarmasin Indonesia \\ 2,3 Universitas Negeri Jakarta, Indonesia
}

\begin{abstract}
In the historical method, a heuristic is an approach to find, collect and organize resources to obtain relevant historical materials according to the topics discussed. This research is a development research that is meant to develop problem statement as a solution of the heuristic problem faced by the students of History Education Program of Faculty of Teacher Training and Education, Lambung Mangkurat University on the Subject of History Method. The steps of this study refer to the development procedures adopted and adapted from those as suggested by [19]. The steps of the model adapted for this research are as follows: (1) need analysis and initial search of information, (2) competence analysis needed, (3) the development of assessment instruments, (4) the development of learning strategies, (5) need analysis on the learning model, (6) conduct of a formative evaluation. The evaluation is in the form of initial test using the one to one test involving 3 students who were representatively chosen. Furthermore, the small group and limited tests were conducted. The test was attended by 57 students determined from the participants of the Historical Method Subject in Study Program of History Education, Faculty of Teacher Training and Education, Lambung Mangkurat University. The results showed that their heuristic ability increased after the pretest and posttest for three times. MPS makes the students more critical in searching historical sources (heuristic competence) and in interpreting the historical sources. As a result, MPS gives an influence towards the students' learning achievement.
\end{abstract}

Keywords: problem statement, heuristic and history education

\section{INTRODUCTION}

Historical work is a representation of the process of interaction between historians and the facts in the present [1] [2]. Searching and collecting the historical materials or historical evidences to know historical events according to the topic to be discussed is called heuristic [3]. Heuristic is the most important part of producing a scientific history.

Some persons still consider History as a study of study political affairs, military, great narrative, narrative writing and they still imagine it as a medium of romantic expression without connecting to the present phenomenon [4]. 
History is still perceived as it oriented to the past about the great events and the roles of the privileged elite as a great narrative, but actually History also examines ordinary human beings in their humane daily activities [5]. A view on the romance of historical science is still going in the study of history. Learners are not given the opportunity for critical thinking. They only receive information from textbooks or orally received from their teachers without criticizing the sources they used, so that teaching and learning of History is regarded as an absolute truth and it does not provide an opportunity for discussion. Meanwhile, the historical work (historiography) is subjective in nature and it becomes a never ending debate material. According to Jenkin and Munslow influenced much by postmodern thought, stating that the model of historical research consists of: reconstruction, construction, and deconstruction [6] [7]. Theoretically this view re-questions the established truth.

Historical education scholars agree to introduce historical research to the learners of history as historical thinking. According to [8], historical thinking requires to bringing two opposing views together: (1) the way of thinking is an inherent legacy, (2) if it cannot be avoided, then use the way to see the past by using the present perspective. This perspective implies that historical thinking envisions the future by teaching the past. In this perspective, History becomes the actual science in which there is continuity. Components of historical thinking consist of: (1) significance, (2) epistemology \& evidence, (3) continuity and change, (4) progress and decline, (5) empathy, and (6) historical agents) [9] [10].

Historical thinking inspires the writers to name the model of learning as Model of Problem Statement (MPS). This model is a synthesis of Problem Solving Model with Issue Centered History Model. Problem solving is a way in the process of learning history on the basis of problems built by the teachers and learners, while the issue centered history model developed by [11] stems from an analogous way of thinking involving learners to relate historical events to contemporary ones [7] [12].

The problem statement is the first step of the MPS to re-question the issue of statements of facts which are usually in the form of documents in accordance with the topics discussed to get accuracy and completeness. In the study of study, the questions are not merely related to names, years, and locations of events but they must be critical towards the historical facts employed the MPS is the trigger for historical thinking. Historical thinking is closely related to historical method. The first step in the historical method is the heuristic, central part for historical research [13]. Operational heuristic begins from search, discovery and collection of written and oral sources as historical facts used for historical evidence. The Jhonson Research 2015 and Bickford III, 2010 found that history learning in the three junior secondary schools still employs history books in which the classes did not criticize the sources used in the books how teachers innovate to trigger student enthusiasm to analyze both primary and secondary historical documents. Similarly, the initial observations towards 10 theses in the Study Program of History Education, Faculty of Teacher Training and Education, Lambung Mangkurat University, Banjarmasin. In implementing historical method, especially heuristic, the theses' writers did not conduct internal and external critiques.

The MPS is the trigger for historical thinking. Historical thinking is closely related to historical method. The first step in the historical method is the heuristic, central part for historical research [13]. Operational heuristic begins from search, discovery and collection of written and oral sources as historical facts used for historical evidence. The Jhonson Research 2015 and Bickford III, 2010 found that history learning in the three junior secondary schools still employs history books in which the classes did not criticize the sources used in the books how teachers innovate to trigger student enthusiasm to analyze both primary and secondary historical documents. Similarly, the initial observations towards 10 theses in the Study 
Program of History Education, Faculty of Teacher Training and Education, Lambung Mangkurat University, Banjarmasin. In implementing historical method, especially heuristic, the theses' writers did not conduct internal and external critiques. So are the students' theses. Students' these with the themes of historical education, just explains how to teach History using the models of learning without criticizing the subject matters. This phenomenon implies that they do not study History. Learning history begins by investigating the past through the search of historical evidence, criticizing and then interpreting it. History without any facts that are criticized and interpreted means that there is no history or this in not history [14] [15].

Historical teaching and learning is not limited to collect or gather historical facts. Historical facts do not show the truth but these refer to the information about an event. The facts obtained are imaginatively interpreted imaginatively and analyzed so that someone can understand historical developments [16] [17] [18]. This view implies that the historical evidence, imagination and interpretation cannot be separated from the study of history as a means of supporting historical truths. Based on that narration, the statement problem can be used to overcome the heuristic problem of students in learning history. Assessment of problem statements to support the students' heuristic capabilities on the basis of the historical documents can be conducted using the assessment technique adopted from The Benchmarks of Historical Thinking Project. In this context, it is necessary to conduct a development research on the Model of Problem Statement (MPS) as a solution of heuristic problem so that the critical students adequately act as the historians in their work.

The local historical themes are selected based on the primordial primacy which have not been adopted and adapted in the national history books. The selected local history materials are not related to the wars or physical conflicts but the issues on land, local irrigation and clothing. Research result is expected in order that the students of Historical Education will be able to become History Teachers who have capabilities to apply strictly heuristic on the basis of the problem statement model, so that they can be critical to their social environment.

\section{METHOD}

This research is a development research that is meant to develop problem statement as a solution of the heuristic problem faced by the students of History Education Program of Faculty of Teacher Training and Education, Lambung Mangkurat University on the Subject of History Method. The steps of this study refer to the development procedures adopted and adapted from those as suggested by Dick and Carey. The steps of the model adapted for this research are as follows: (1) need analysis and initial search of information, (2) competence analysis needed, (3) the development of assessment instruments, (4) the development of learning strategies, (5) need analysis on the learning model, (6) conduct of a formative evaluation [19].

Need analysis as the first step is done by looking at the results of S1 theses in the Studying Room of History Education Study Program. The results of the observations show that the weakness of the theses is in the heuristic problems and the source critiques. This finding is expected to be useful as a basis for designing the initial draft of the model. Competency analysis is conducted through the library studies on how to construct history based on methods, critical thinking attributes and interactive skills. Competence is obtained through reference books on methods and historical methodologies. The assessment instrument in the developed model is constructed using the reference of assessment criteria. This reference of assessment criteria assumes that everyone can learn anything. Test is conducted using the pretest and posttest. The chosen learning strategy is a micro teaching strategy. It is started by 
introducing the topic of discussion to be discussed in the learning and teaching process up to the achievement of general goals. Local history themes are selected for the subject matter because they are often ignored by the students. Supporting media in this research cover the documents and historical photographs because these are considered effective and efficient for supporting the subject matter on the local history.

As suggested by Dick and Carey, this model does not include the expert engagements to review the product. This research involves one historian and one expert of history education experts to review the product. The agreement between the historian and expert of history education is used as suggested by Cohen Kappa. Afterwards, the formative evaluation is conducted with the aims of describing the development of materials, instruments, and developing formative evaluation plan; the researchers then: (1) conduct one to one test, (2) evaluate small group consisting of 20 students, (3) tryout involving 57 students and revise of selected teaching materials. The data collected in this research are qualitative and quantitative data. Qualitative data are in the form of expert validation on the material, construction and language, description of the learning and teaching process. Notes in group discussions are used to validate data obtained from interviews. Questionnaire is in the form of open questions that are meant to obtain information of the complaints, what is known and what is required in the lecture. Quantitative data are in the form of pretest and posttest that are used to measure the change of knowledge and the students' understanding of the material given during the lecture through the Subject of Historical Methods by using the t-test.

\section{RESULTS}

\subsection{Problem Statement Model}

The Model of Problem Statement (MPS) is a synthesis of the dialog between the problem based learning (PBL) model with the historical central issues. This model is modified from the Dick and Carey's model in the research included into the procedural model. This research is meant to solve heuristic problem in history learning and teaching using problem statement model, especially in the Subject of History Method.

Implementation of Model of Problem Statement (MPS) in the Subject of Historical Method at the Study Program of History Education, Faculty of Teacher Training and Education, Lambung Mangkurat University is a new experience. This model is tested on the fourth semester students who take the Subject of Historical Method. The Subject of Historical Method discusses the ways to learn the science of history and the process of historical research. The topics tested in in the small and limited group consist of historical sources and archives, land, land ownership, local irrigation, and clothing. This topics are indeed local, intended that the students can know and analyze problems in their own region. The evaluation in this study is based on the steps of Dick and Carey's model, namely: formative evaluation, consisting of one to one, small group evaluation and limited test in the real class. The selected test is in the form of a description question. The descriptive questions are made on the basis of consideration: (a) to know the understanding on the materials that have been presented, and (b) to stimulate the students to express their opinions in their own language. The product of development on this model has been reviewed by a historian and an expert of education. The one to one evaluation is intended to get information on the students' interest and comments. This evaluation involves three students with high, fair, and low levels of academic achievements. These three students are tested about the development of statement problem model. They are interested in the Model of Problem Statement (MPS) because it enables them to relate actual social issues to the past time, and to see historical phenomena on the basis of 
their own points of view. They acknowledge their own weaknesses; they lack of reading materials, and they require comprehensive reading materials that are learned together with the historical sources.

The small group evaluation involves 20 students. The results show that the pretest scores are as follows. 15 are the lowest score; 60 is the highest score, and the average score is 32.33 . Meanwhile, the posttest score are as follows. 40 are the lowest score; 87.50 are the highest score; and 70.13 are the average score. The result of t-test shows that there is a significant difference between the results of pretest and of the posttest. The t-count, t-table, $10.83>0.68920$ with a.50. the score shows that problem statement can increase the students' heuristic competence. In the pretest, they obtain the bad score. This is because they have not well prepared the learning materials. The reference books and modules, by which the students can get the discourse to think critically and present it in learning and teaching activities, are very limited. According to the observer, in the process of learning and teaching the lecturer played roles on the tract; he gave explanation and reinforcement when the students did not have understanding on the result of analysis either in individual or in group. The students seemed interested in the learning and teaching process. This is because the students were the subjects in the learning and teaching process. The result of posttest towards the small group and learning and teaching strategy that is easily attended show that the limited test can be conducted.

\subsection{Limited Test}

Limited test has been conducted 3 times of meetings. It has been attended by 57 students of Batch of 2015. The results of pretest and posttest from the small group test up to the limited test can be shown in the following table.

The analysis is meant to know the differences of meeting 1, 2 and 3 using the t-test based on SPPS 25. The result shows that there is a difference of the result of posttest in the meeting 1 and 2 with the value of sig. $<0,05$. Also, there is a difference of the result of the posttest in the meeting 2 and 3 with the value of sig $<0,05$. This shows that the value of posttest in the meeting $2>$ the value of posttest in the meeting 1 ; whereas the values of posttest in the meeting $3>$ the value of posttest in the meeting 2 . There is an increase of the result of posttest after the treatment. The values of posttest show increases since the meeting 1 up to the meeting 3. The lowest score in the meeting 1 is 60 and the highest score is 75 . The lowest score shows that the student is not competent, because he was lack of reading the subject matter presented. There is an increase in the values in the meeting 1,2 , and 3 . The average value of posttest in the meeting 1 is 69.21 . There is an increase up to 72.72 in the meeting 2 . The average value of posttest in the meeting 3 is 75.44 . The increase of value in the pretest to that in the posttest shows that the students can comprehend Model of Problem Statement (MPS) in the learning and teaching of history.

\section{DISCUSSION}

Model of Problem Statement (MPS) is an attempt to re-question the statements of historical facts that typically form the contents of written documents. This Model of Problem Statement (MPS) discusses how to relate actual social issues to historical phenomena. The use of the model is in line with the research of [20]on the updated models in order that the students have a sense of historical empathy. The model used in this research is implemented through several steps, namely: interview, small group test and limited test. The result of interviews towards 3 students shows that they were interested in the model. Their interest is 
constructed based on deconstruction approach; their weakness is seen from their heuristic activities and interpretation. According to deconstruction approach, the history that examines the past is relative, thus it provides an opportunity to criticize the narrative written by others [5] [6] [21]. The Model of Problem Statement (MPS) provides opportunity to relate actual social issues to the past time and to interpret historical phenomena from their own points of view. The local resistance to the occupation of colonial, containing the violent narratives, has a final limit and is characterized by the occupied people's defeat can be reconstructed into a variety of dynamic narratives that are always actual.

The result of posttest in the small group evaluation is in the average of 70.13 . This posttest is conducted on the basis of the implementation of problem statement model, involving 20 students; and the materials to be tested are the subject matters of Historical Method. The result shows that the students have heuristic competencies to find and to manage historical facts, namely: documents, newspaper, journals and photographs; the students have competencies to criticize the historical facts; and also they can differentiate the primary sources from secondary ones. The students' knowledge on historical facts (why, what, how, and direction of which the events happened) have increased, so that using their imagination they can differentiate the soul of every era [22] [23]. These steps stimulate the students of History Education work as they are the history researcher [24]. The limited test has been conducted three times. This test involved 57 students. The test of posttest shows the result as follows. The average results are: the meeting 1,69.21, the meeting 2, 72.77, and the meeting 3, 75.44. These results provide information that the students have comprehended the Model of Problem Statement in attending the subject of History Method. This is based on the fact, that the learning and teaching process during the treatment using MPS has covered the actual problems of local region, and has been continued by the problems experienced by the students at present time. In order to create an active social process, the learning and teaching of history is necessary to be based on the available culture and materials. The lecturer may determine the themes on land, local irrigation, and clothing to which the national history never discuss [25] [7] [24]. Selected materials are based on the consideration that the local history provides much information so that it can be placed on the same position as -and at the same time it can be used to support- the national history [26] [5].

The materials on land, irrigation, and clothing are categorized as those of social history; these materials discuss the activities of the various social communities, covering education, economy, socio-culture, technology, kinship, and sport in the society. The materials on social history as used for the subject matters are also employed by [26], on labors (workers); by Tadmor (2010) on kinship built through genealogical and marital relationship, and by [6] on the history of sports, although the problems and objectives are different from one and another. Through the Model of Problem Statement (MPS), the students can realize that understanding the local history means understanding the diversity of communities and social stratification on the basis of the problems they have faced in history. The material of the first discussion is about the problem of land in South Kalimantan. Land is always related to its use by the government. In the nineteenth century in the Sultanate of Banjarmasin, rightly in the era of Sultan Adam, the use of land in the area of the sultanate was well ruled. In the rule, in order to be productive the land is lent to anyone. The land will be withdrawn by the sultanate if in the period of 2 years the land is cultivated, and it is lent to anyone who needs it. In 1970-s, in Banjarmasin and Martapura, the land was freely possessed as long as the inhabitants cultivated it. At the present time the land has been the actual issue concerning the dual ownership and its utilization. 
The material of the second discussion is about irrigation in South Kalimantan. Geographically, Banjarese Community, especially who live in Banjarmasin and Martapura, is surrounded by river and its tributaries. The physical environment faced by Banjarese community makes them build their river culture. They developed the tidal system, tidal farming, and built the waterways for transportation. In the period of development, the waterways or channels have been partly dumped. As a consequence, this condition makes flood somewhere. The tributaries and waterways splitting the city have not been functioned anymore for the sake of transportation. The third material in the third discussion is about the clothes or clothing. This material is always actual one. Functionally, clothes are used for covering aura (body) and for showing identity. This is to say that the hijab cloth has function for covering aurat and for showing the identity of the users as Muslim women. At the present time, the clothes are not only seen from the viewpoint of function, these are also seen from those of the users' status. The hijab cloth as the Muslim women's identity does not change. This means that hijab cloth may be related to its price and mode. From the viewpoint of price, it may be sold in cheap or expensive price; form the viewpoint of mode, it may be in the form of usual or sexy mode. The hijab cloth with high or expensive price may show luxury for its users. Sometimes hijab cloth is designed in the form of sexy mode to show the contemporary mode. In fact, sometimes hijab cloth in sexy model breaks the rule of dressing with hijab.

The researches in which the researchers implement Model of Problem Statement (MPS) followed by re-interpreting the historical facts present the actual subject matters. Identifies and interprets the historical materials by [6]. This is meant to present the essence of contemporary historical practice through deconstruction. The historical facts employed are the official documents, verbal testimonies, films, and photographs of the actors and the other supporting materials. The result shows that the deconstructed facts are regarded as difficult ones. This is because the deconstruction requires the more advanced or sophisticated contextualization and theorization [6] [14]. In order that the students can practice their empathy towards the interpretation of facts as to understand and obtain many interpretations, it is necessary to build working group to collaborate with the group members and to discuss with the other group. The debate in group makes the students realize that they can identify sources, differentiate facts from historical interpretation, relate the past time to the present time (historical continuation), comprehend the past time that is different from the present time, and give empathy based on the interpreter's imagination [23].

\section{CONCLUSION}

The Model of Problem Statement (MPS) plays an important role in solving heuristic problems. The result of pretest of the students of Study Program of History Education, Faculty of Teacher Training and Education, Lambung Mangkurat University increased from the meeting 1 up to the meeting 3. The result of their posttest also increased from the meeting 1 up to the meeting 3. This is to say that MPS makes the students more critical in searching historical sources (heuristic competence) and in interpreting the historical sources. As a result, MPS gives an influence towards the students' learning achievement.

\section{REFERENCES}

[1] C. V. dan C. S. Langlois, Introduction to The Study of History. Yogyakarta: Indoliterasi, 2015.

[2] E. H. Carr, Apa itu Sejarah. Jakarta: Komunitas Bambu, 2014.

[3] F. Sayer, Sejarah Publik. Yogyakarta: Ombak, 2017. 
[4] G. Himmelfarb, The New History and The Old. Cambridge, Massachustts and London: The Belknap Press of Harvard University Press, 1987.

[5] B. Purwanto, Gagalnya Historiografi. Yogyakarta: Penerbit Ombak, 2006.

[6] D. Booth, "Evidence revisited: Interpreting historical materials in sport history," Rethink. Hist., vol. 9, no. 4, pp. 459-483, 2005.

[7] N. Supriatna, "Dekonstruksi Sejarah Perang Kerajaan-Kerajaan Islam Di Asia Tenggara Dalam Pedagogi Sejarah," Hist. J. Pendidik dan Peneliti Sej., vol. 9, no. 2, p. 114, 2008.

[8] S. Wineburg, Historical Thinking and other Unnatural Acr Charting the Furure of Teaching the Past. Philidelphia: Temple University Press, 2001.

[9] P. dan Seixas and Carla Peck, Teaching Historical Thinking. Vancouver: Pacufuc Educational Press, 2004.

[10] C. Duquette, "Relating historical consciousness to historical thinking through assessment," in New directions in assessing historical thinking, K. Ercikan \& P. Seixas, Ed. New York: Routledge, 2015, pp. 51-63.

[11] P. Ferguson, "Teaching Issues-Centered History," in Handbook on Teaching History, Ronald W. Evans dan David Warren Saxe, Ed. Washington: National Council for the Social Studies, 1996, p. 132.

[12] L. Armiyati, "Menggali Kreativitas Peserta Didik Melalui Inovasi Model Issues Centered History Dengan Media Film dalam Pembelajaran Sejarah," in Prosiding Seminar Nasional Pembelajaran Sejarah Di Tengah Perubahan, 2014, p. 223.

[13] C. \& L. K. Kolbel, Historical Conscioness In German. New York and London: Routledge, 2015.

[14] D. Rosenlund, "Source criticism in the classroom: An empiricist straitjacket on pupils' historical thinking?," Hist. Encount., vol. 2, no. 1, pp. 47-57, 2015.

[15] C. Salinas, M. E. Bellows, and H. L. Liaw, "Preservice Social Studies Teachers' Historical Thinking and Digitized Primary Sources: What They Use and Why," Contemp. Issues Technol. Teach. Educ., vol. 11, no. 2, pp. 184-204, 2011.

[16] C. B. McCullagh, Logic of History Perspektif. Yogyakarta: Lilin Persada Press, 2010.

[17] Y. Suh, "Past Looking: Using Arts as Historical Evidence in Teaching History.," Soc. Stud. Res. Pract., vol. 8, no. 1, p. 135-159 25p, 2013.

[18] B. dan M. K. Garvey, Model-Model Pembelajaran Sejarah di Sekolah Menengah. Yogyakarta: Ombak, 2015.

[19] W. L. C. \& J. O. C. Dick, The Systematic Design of Instruction. New Jersey Colombus, Ohio: Person Education Limited, 2013.

[20] J. L. dan S. B. Endacott, "An updated theoretical and practical model for promoting historical empathy," Soc. Stud. Res. Pract., vol. 8, no. 1, pp. 41-58, 2013.

[21] D. J. Staley, “A History of The Future,” Hist. Theory, vol. 41, no. 41, pp. 72-89, 2002.

[22] Kuntowijoyo, Penjelasan Sejarah. Yogyakarta: Tiara Wacana, 2008.

[23] J. Jensen, "Developing Historical Empathy through Debate: An Action Research Study," Soc. Stud. Res. Pract., vol. 3, no. 1, pp. 55-67, 2008.

[24] L. M. and J. L. P. Westhaft, "Developing Preservice Teachers' Pedagogical Content Knowledge about Historical Thinking," Int. J. Soc. Educ., vol. 22, no. 2, pp. 1-28, 2008.

[25] H. Sutherland, "Meneliti Sejarah Penulisan Sejarah," in Perspektif Baru Penulisan Sejarah Indonesia, B. P. dan R. S. Henk Schulte, Ed. Jakarta: Yayasan Obor Indonesia, 2008, p. 34.

[26] S. Demers and D. Lefrançois, "Understanding agency and developing historical thinking through labour history in elementary school : A local history learning experience," Hist. Encount., vol. 2, no. 1, pp. 34-46, 2015. 
[27] N. Tadmor, Early modern English kinship in the long run: Reflections on continuity and change, vol. 25, no. 1. 2010. 